\title{
Synthesis of colloidal nanoparticles CdS:Mn in the polymer solution for biological applications
}

\author{
V.I.Fediv, G.Yu.Rudko ${ }^{*}$, A.I.Savchuk ${ }^{* *}$, E.G.Gule ${ }^{*}$, I.S.Davydenko \\ Department of Biophysics and Medical Informatics, Bukovinian State \\ Medical University, 42 Kobylianska Str., 58000 Chernivtsi, Ukraine \\ *V.Lashkaryov Institute of Semiconductor Physics, National Academy of \\ Sciences of Ukraine, 45 Nauki Ave., 03028 Kyiv, Ukraine \\ *** Chernivtsi National University, 2 Kotsyubynsky Str., \\ 58012 Chernivtsi, Ukraine
}

Received December 25, 2013

\begin{abstract}
Kinetics of the colloidal CdS:Mn nanoparticles synthesis in the solutions of polyvinyl pirrolidone and mixture of polyvinyl pirrolidone with polyvinyl alcohol is studied by optical absorption method. The dependences of NPs size, polydispersity index and concentration of NPs on the precursors concentration in the growth solution are studied. The factors that affect the characteristics of colloidal nanoparticles are analyzed. It is shown that growing in the mixture of macromolecules improves the synthesis kinetics and provides stabilization of the average nanoparticles size in wide range of precursors concentration. The possibility to use the colloidal solutions polymer/nano-CdS:Mn as light-emitting labels in whole blood was demonstrated.
\end{abstract}

Исследована кинетика синтеза коллоидных наночастиц CdS:Mn в растворах поливинилпирролидона и смеси поливинилпирролидона с поливиниловым спиртом методами оптического поглощения. Определены зависимости размера, показателя полидисперсности и концентрации наночастиц от концентрации прекурсоров в растворе. Проанализированы факторы, которые влияют на характеристики коллоидных наночастиц. Показано, что использование смеси макромолекул полимера влияет на кинетику синтеза и обеспечивает стабилизацию среднего размера наночастиц в более широком диапазоне концентраций прекурсоров по сравнению с раствором одного полимера. Продемонстрирована возможность использования наночастиц, синтезированных в растворе поливинилпирролидона, в качестве люминесцентных меток для исследований цельной крови.

Синтез колоїдних наночастинок CdS:Mn у розчині полімеру для біологічних досліджень. В.І.Федів, Г.Ю.Рудько, А.Й.Савчук, Є.Г.Гуле, І.С.Давиденко.

Досліджено кінетику синтезу колоїдних наночастинок CdS:Mn у розчинах полівінілпіролідону та суміші полівінілпіролідону і полівінілового спирту методами оптичного поглинання. Визначено залежності розміру, показника полідисперсності та концентрації наночастинок від концентрації прекурсорів у розчині. Проаналізовано фактори, які впливають на характеристики колоїдних наночастинок. Виявлено, що використання суміші макромолекул полімерів впливає на кінетику синтезу і забезпечує стабілізацію середнього розміру наночастинок у ширшому діапазоні концентрацій прекурсорів порівняно з розчином одного полімеру. Продемонстровано можливість використання наночастинок, синтезованих у розчині полівінілпіролідону, в якості люмінесцентних міток для досліджень цільної крові. 


\section{Introduction}

An important task of modern nano-technologies is the development and improvement of the facile methods of controllable nanoparticles (NPs) fabrication. Light-emitting NPs can be effectively used both in electro-luminescent devices and as biological labels [1, 2]. Among the most frequently used methods of NPs production the colloidal synthesis is known to be the cheapest one and, therefore, it is perspective for mass production of NPs.

During a colloidal synthesis the size of NPs is restricted by the presence of capping agents in the solution. The choice of the capping agent strongly influences the lightemitting properties and structure of the NPs synthesized. The water-soluble polymers (polyvinyl alcohol, polyvinyl pyrrolidone, gelatine, etc.) are attractive for the colloidal synthesis because they can be easily integrated with various inorganic substances, the molecular mass of these polymers can be varied in wide range, they are cheap, optically transparent and easy-toshape, i.e., the polymer-based colloidal solutions can assume any shape after drying of the colloid $[3-5]$. The solubility in water permits to avoid toxic solvents. The special advantage of the above polymers is their biocompatibility that makes these colloids suitable for applications in the studies of living beings in vivo. These applications are based on the emission of light by NPs, so the direct band semiconductors are widely used and, in particular, CdS NPs are suitable for the direct visualization of certain processes in biological objects because they emit light in the visible range. Additional functionality of such bio-labels can be added by doping with magnetic ions that provides the possibilities to control NPs by applying magnetic field.

The colloidal growth of NPs occurs via the precipitation in the oversaturated solution. Precipitation involves the processes of seed formation and further growth. Strong mutual influence of both processes during the NPs formation essentially sophisticates their analytical description; therefore at present the understanding of the kinetics of seed formation and particles growth is not complete. This impedes the optimization of growth processes and finding the routes for fabricating NPs with predictable properties. Therefore, the experimental study of the kinetics of the colloidal synthesis is the main source of information on the details of NPs growth.

The aim of the present study was to analyze the influence of the nature of organic substances in the growth solution on the characteristics of NPs, and to find out whether the CdS:Mn NPs thus synthesized can be used for creation of light-emitting bio-sensors.

\section{Experimental}

Nanoparticles CdS:Mn were synthesized by chemical precipitation route in the water solutions containing ions $\mathrm{Cd}^{2+}, \mathrm{Mn}^{2+}, \mathrm{S}^{2-}$, polyvinyl pirrolidone (PVP) and polyvinyl alcohol (PVA). The salts cadmium chloride $\left(\mathrm{CdCl}_{2}\right)$, sodium sulfide $\left(\mathrm{Na}_{2} \mathrm{~S}\right)$, manganese chloride $\left(\mathrm{MnCl}_{2}\right)$ were analytical grade and were used with no further purification. Synthesis was carried out at $\mathrm{pH}(4-5)$. The solutions of these salts of the concentrations $0.1 \mathrm{~mol} / \mathrm{g}$ were prepared using the bidistilled water.

Optimal synthesis conditions $(\mathrm{pH}$ value and precursors concentrations) were chosen in accordance with [6] to avoid the formation of the precipitates of $\mathrm{MnS}, \mathrm{Mn}(\mathrm{OH})_{2}$ and $\mathrm{Cd}(\mathrm{OH})_{2}$ and to provide the colloidal solution containing CdS:Mn NPs. Concentrations of $\mathrm{Cd}^{2+}$ ions and polymer were varied, respectively, in the range $(1-30 \mathrm{mM})$ and $(1-5)$ wt. $\%$ in all synthesis procedures. Concentration of $\mathrm{Mn}^{2+}$ ions in the synthesis solutions was $5 \cdot 10^{-3} \mathrm{M}$. Absorption spectra of the colloidal solution were studies using the grating spectrometer MDR-23.

Calculations of the NPs parameters (average radius, concentration, polydispersity index) were done by the following schemes. Calculations of the average radius of NPs.

Optical band gap was obtained from the absorption spectra using the "knee" method

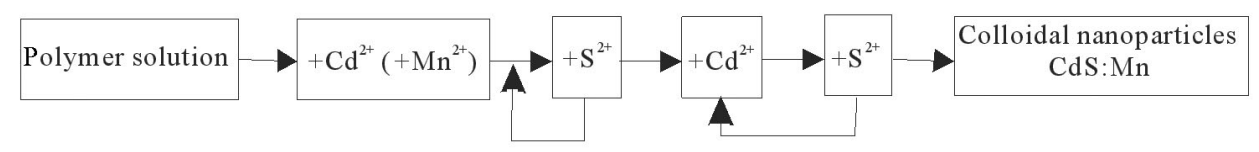

Fig. 1. Sequence of the steps of CdS:Mn NPs synthesis in the water solution of polymers. 

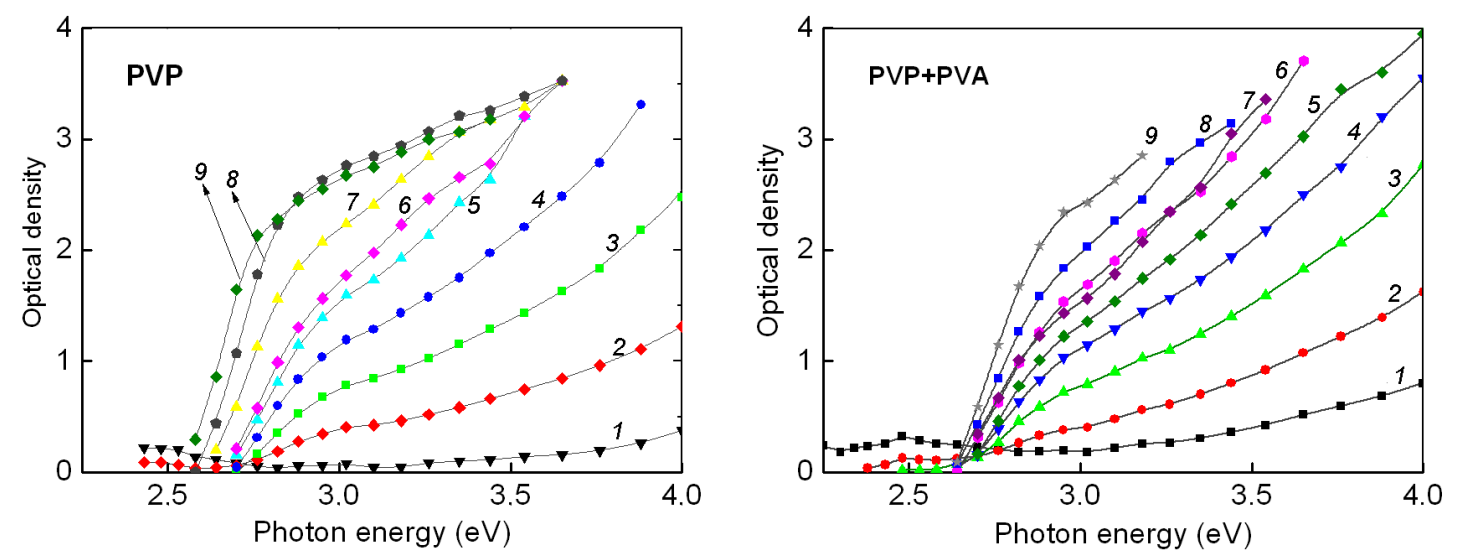

Fig. 2. Spectral dependences of the optical density of CdS:Mn NPs synthesized in the water solutions of PVP (a) and PVP+PVA (b) measured at different steps of the growing procedure (shown in Fig. 1).

[7] and the second derivative of the absorption spectra [8]. Based on the band gap values obtained the average radius $R$ of NPs was estimated in the effective mass theory approximation $[9,10]$ by the formula:

$$
\Delta E_{g}=\frac{\pi^{2} \hbar^{2}}{2 R^{2}}\left(\frac{1}{m_{e}}+\frac{1}{m_{h}}\right)-\frac{1.8 e^{2}}{\varepsilon R},
$$

where $\Delta E_{g}$ is the difference between the band gap of NPs and the bulk CdS crystal (2.42 eV).

Calculations of NPs concentration

To estimate the NPs concentrations at different precursor concentrations we have used the following assumptions:

- the synthesized nanoparticles are spherical;

- incorporation of Mn impurity does not influence the band gap of NPs because the content of impurity is low;

- excess of the sulphur ions in the growth solution provides complete incorporation of cadmium ions into the NPs, thus, there are no free Cd ions in the solution;

- to simplify the calculations we used the cubic cell for CdS lattice.

After obtaining the radius of NPs we calculated the number of cadmium atoms in one NP using the formula:

$$
N=\frac{\frac{4}{3} \pi\left(\frac{D}{2}\right)^{3}}{8 a^{3}} .
$$

The volume of the cubic crystalline cell is $V=a^{3}$, where $a$ is the lattice constant (for CdS $a=0.58 \mathrm{~nm}$ ), $D$ - diameter of nanoparticle.
Concentration of NPs was calculated as a ratio between the concentration of $\mathrm{Cd}$ atoms (or $S$ atoms, depending on the synthesis stage) in the solution to the number of atoms in a single NP:

$$
C_{n p}=\frac{\left(C_{\mathrm{Cd}^{2+}} o r \mathrm{~S}^{2-}\right) \cdot N_{A}}{N} .
$$

Calculations of the radius polydispersity index (RPI).

The polydispersity of NPs can be expresses via standard deviation $\sigma$ of particles sizes distribution (it is also called the absolute polydispersity) and the average diameter of NPs $\left(2 R_{\text {avg }}\right)[11,12]$ :

$$
\mathrm{RPI}=\left(\sigma / 2 R_{a v g}\right)^{2}+1,
$$

where RPI $=1$ defines a monodisperse sample.

In the assumption of Gaussian distribution of NPs diameters the standard deviation $\sigma$ corresponds to the half-width of the particle size distribution [13]:

$$
\sigma=2 R_{\text {edge }}-2 R_{\text {avg }}
$$

where $R_{\text {edge }}$ corresponds to the average value of the largest NPs sizes, $R_{\text {avg }}$ corresponds to the particle size most frequently found in the distribution. The values $R_{\text {edge }}$ and $R_{\text {avg }}$ were calculated from the absorption spectra by formula (1).

Using the above formulae we analyzed the changes of NPs polydispersity during the growth process using the absorption spectra measured at each stage of the synthesis (shown in Fig. 3, a and b). 

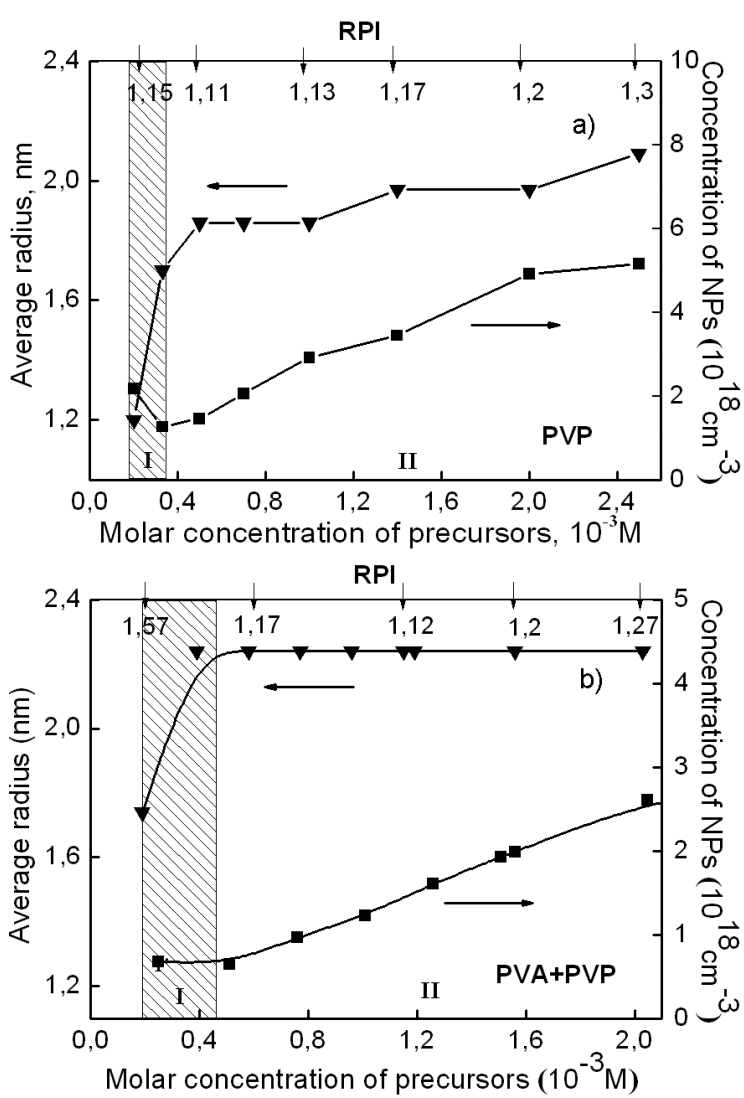

Fig. 3. Dependences of the average radius of NPs and NPs concentration on the precursors concentration. The polydispersity index of size distribution obtained for each synthesis step is labeled on the top axis. Each point on the graphs corresponds to a curve in Figs. 2a, b.

\section{Results and discussion}

The main characteristics of NPs are determined by the conditions of synthesis, the size of NPs, their polydispersity and stability. To find optimal balance of these parameters we studied the kinetics of NPs synthesis by optical absorption method.

The sequence of the synthesis steps is illustrated by the diagram 1 . The absorption spectra of the growth solution were measured after each synthesis step (Fig. 2a, b); they reflect the evolution of the optical properties of the colloid caused by the changes of the qualitative and quantitative composition of the solutions.

It is seen (curves 1, Fig. 2a and b) that the water solution of the PVP or PVP+PVA that contains only the precursors $\mathrm{MnCl}_{2}$ and $\mathrm{CdCl}_{2}$ (step 1 in Fig. 1) is transparent in the spectral range $300-700 \mathrm{~nm}$. Injection of the precursor $\mathrm{Na}_{2} \mathrm{~S}$ into this solution leads to the formation of CdS:Mn seeds and the slight increase of the absorption (curves 2,

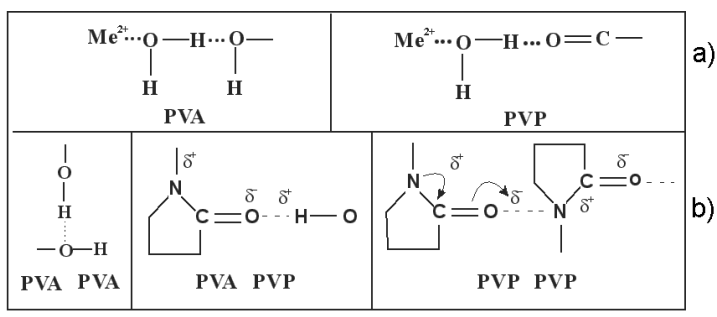

Fig. 4. a) Schemes of the hydrogen bonds between the metal ion on the surface of a NP and functional groups of polymers; b) Possible interchain interactions in the water solutions of PVP-PVA mixture.

Fig. 2a, b). During the following synthesis steps the absorption gradually increases and the absorption edge moves towards lower energies thus reflecting the increase of NPs content and average size.

To analyze the kinetics of NPs synthesis one has to take into account two processes which can simultaneously occur in the same solution: NPs nucleation (formation of NPs seeds) and their following growth. The distribution of NPs sizes depends on the stage of growth, i.e. on the number of precursor injection steps, precursor diffusion towards the NP surface, binding of the precursors to the surface. Two main processes govern the NPs formation: the diffusion (movement of precursors towards a NP surface) and growth (the binding of adsorbed molecules to the surface). If the precursor concentration becomes lower than the minimum concentration that is necessary for nucleation, then the growth of the already existing NP is determined by the diffusion of precursors towards the surface of NP. If this diffusion is sufficiently quick then the growth occurs solely via the processes on the surface [14].

The behavior of the disperse systems containing polymers is to a great extent conditioned by the absorptive interaction of the macromolecules with the surface of the particles of the disperse phase and by the intermolecular interactions in polymer $[15,16]$. Important factors that determine the mechanism of colloidal particles stabilization are the formation of complexes of polymers with metallic ions (in our case $\mathrm{Cd}^{2+}$ ) and the processes of ions hydration.

The authors of [17] studied the formation of the complexes of $\mathrm{Cd}^{2+}$ with molecules of PVP and PVA and demonstrated that thermodynamic stability constants are 9.1.10 $0^{4}$ and $2.3 \cdot 10^{4}$ for $\mathrm{Cd}^{2+}-\mathrm{PVP}$ and $\mathrm{Cd}^{2+}$ PVA, respectively. The enthalpy of the reac- 
tions is -0.75 and $-0.23 \mathrm{~kJ} / \mathrm{mol}$ for $\mathrm{Cd}^{2+}$ PVP and $\mathrm{Cd}^{2+}$-PVA, respectively. The negative sign of the enthalpy value points to the formation of stable complexes $\mathrm{Cd}^{2+}$-PVP and $\mathrm{Cd}^{2+}$-PVA, and the ability of complex formation is higher for PVP. Due to the overlapping of molecular orbitals of PVP with atomic orbitals of metal ions, particularly with the ones located on the surface, the donor-acceptor bonds with the groups $\mathrm{C}=\mathrm{O}$ and $\mathrm{N}$ arise. These interactions can cause alteration of the tautomeric form of the organic molecules adsorbed on the surface due to the change of effective charge on $\mathrm{N}$ and $\mathrm{C}=\mathrm{O}$; as a result, the electron delocalization varies with the concentration, type of the solvent and with the intermolecular interactions in the chemically adsorbed layers [18].

Another process that plays an important role in the formation of the adsorptive complex compounds in the systems $\mathrm{Me}^{n+}-$ polymer-adsorbent is the hydration of NP surface $[19,20]$. According to the NMR data $[20,21]$ water soluble polymers are strongly hydrated in the solutions, their chains bind 2-3 water molecules. The water molecules that are bound with exchange cations are not replaced by the adsorbed polymer molecules and form the hydrogen bonds with functional groups of polymer molecules Fig. 4a).

Adsoption of water-soluble polymers containing hydrophilic groups on the surface of colloidal particles usually causes essential hydrophilization of the disperse phase surface and, correspondingly, causes the increasing of the role of hydration. However, it is difficult to quantitatively estimate the contribution of hydration to the mechanism of the stabilization of polymer-containing disperse systems [22].

Analyzing the kinetics of NPs formation we distinguished two main stages of growth (labeled as I and II in Fig. 2a, b). Fig. 3 shows the dependence of the average NP radius and their number in the unit volume on the concentration of precursors. The polydispersity index of size distribution obtained for various synthesis steps is labeled on the top axis. Observation of the abrupt change of these parameters with the concentration of precursors at the very beginning of NPs formation (stage I) agrees with the main postulates of the classical Ostwald ripening theory. This theory [23] describes the NPs growth at early stages when the smaller NPs dissolve and their material is involved in the growth of larger NPs. In-

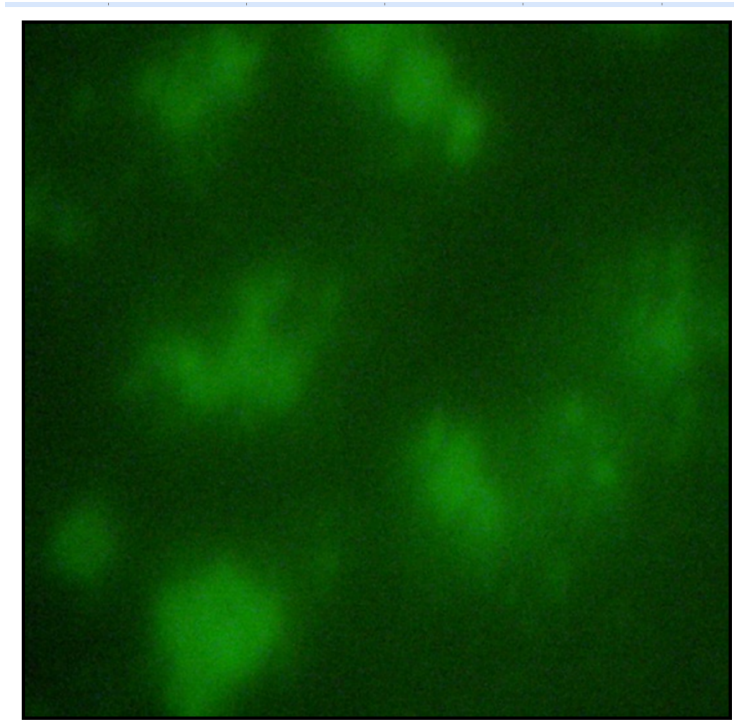

Fig. 5. Image of CdS:Mn NPs in the whole blood (photoluminescence microscopy photo).

crease of the precursors concentration activates both the formation of new NPs seeds and the increasing of the already existing NPs radius (stage II).

To optimize the kinetics of CdS:Mn NP growth, i.e., to increase the range of precursors concentrations where the average radius remains constant, the synthesis conditions were varied by adjusting $\mathrm{pH}$ values and adding another water soluble polymer, PVA, to the solution of PVP. Fig. 3, b shows the dependence of the average NPs radius as well as NPs concentration on the precursors concentration in the solution of the polymeric mixture PVP + PVA at $\mathrm{pH}$ 4,5. It should be noted that in this case the average size of NPs remains invariable in the wide range of precursors concentrations which makes adjusting of synthesis conditions much easier. The reason of such a favorable behavior is larger thickness of adsorptive layers on the surface of NPs grown in polymer mixtures as compared to the NPs grown in individual polymer solutions [24]. As a result the stabilizing ability of polymers is better. Another important factor that leads to the differences in the growth kinetics is the interaction between polymer macromolecules [16]. In the polar solvents these are the polymer-solvent and polymer-polymer interactions. In $[25,26]$ the interactions PVP-water and PVA-water were studied experimentally. Homo- and hetero-interchain interaction in these systems is schematically shown in Fig. 4 b. 
Homo-interchain interaction in PVP is caused by the dipole-dipole interaction and in PVA - by the formation of hydrogen bonds. Hetero-interchain interaction in the system PVP-PVA is caused by the formation of hydrogen bonds between the carbonyl groups of cationic PVP and hydroxyl groups of non-ionic PVA. In [27] it is shown that the energy of interchain interaction in the solid solutions of PVP-PVA varies as PVAPVA $<$ PVA-PVP $<$ PVP-PVP.

The interest in the colloidal solutions of CdS:Mn NPs is also caused by their possible application for bio-medical purposes. It is especially true for the colloids based on PVP or PVA that are biologically friendly substances. It is known that PVP is widely used as a blood substitude [28] thus one can expect that the NPs covered with PVP molecules must be compatible with blood. We have checked the applicability of CdS:Mn NPs synthesized in PVP as luminescent markers and have shown that NPs preserve their light-emitting properties being introduces into whole blood. Fig. 5 shows the photo of the samples of whole blood containing these NPs obtained with fluorescent microscope. The fact that PL of these NPs does not disappear in blood makes these NPs promising for application of human blood studies.

\section{Conclusions}

The influence of the qualitative and quantitative composition of the system $\left(\mathrm{Cd}^{2+}-\mathrm{Mn}^{2+}-\mathrm{S}^{2}--\right.$ polymer $\left.-\mathrm{H}_{2} \mathrm{O}\right)$ on the kinetic parameters of the synthesis and the stability of CdS:Mn NPs is investigated. The evolution of the NPs average size during the synthesis in polymer solutions (PVP and mixture PVP + PVA) at varying precursors concentrations is analyzed. It is shown that growing in PVA provides steady increase of NPs average radius while during the growth in the mixture PVA + PVP the radius on NPs is stabilized at the early stages of synthesis and does not change with further additions of precursors. This behavior is caused by the interaction of different macromolecules with the surface of NPs and each other. Early stabilization NPs average radius during the growth makes the adjusting of synthesis conditions much easier.

The possibility to use the colloidal solutions polymer/nano-CdS:Mn as light-emitting labels in whole blood was demonstrated.

\section{References}

1. X.Michalet, F.F.Pinaud, L.A.Bentolila et al., Science, 307, 538 (2005).

2. Y.-J.Doh, K.N.Maher, L.Ouyang et al., Nano Lett., 8, 4552 (2008).

3. Y.-C.Chu, C.-C.Wang, C.-Y.Chen, Nanotechnology, 16, 58 (2005).

4. M.Pattabi, B.S.Amma, K.Manzoor, Mater. Res. Bull., 42, 828 (2007).

5. A.Pucci, M.Boccia, F.Galembeck et al., React. \& Function Polymers, 68, 1144 (2008).

6. A.I.Savchuk, A.G.Voloshchuk, V.I.Fediv, Phys. and Chem. Solid State, 10, 144 (2009).

7. S.Avivi, O.Palchik, V.Palchik et al., Chem. Mater., 13, 2195 (2001).

8. J.Planelles-Arago, E.Cordoncillo, R.A.S.Ferreira et al., J.Mater.Chem., 21, 1162 (2011).

9. L.Brus, J.Chem. Phys., 80, 4403 (1984).

10. M.H.Entezari, N.Ghows, Ultrason. Sonochem., 18, 127 (2011).

11. S.W.Yeh, T.L.Wu, K.H.Wei et al., J.Polymer Sci. Part B: Polymer Phys., 43, 1220 (2005).

12. M.Moffitt, A. Eisenberg, Chem. Mater., 7, 1178 (1995).

13. M.Moffitt, H.Vali, A.Eisenberg, Chem. Mater., 10, 1021 (1998).

14. G.Cao, Nanostructures and Nanomaterials, Imperial College Press, London, (2004).

15. A.A.Baran, B.E.Platonov, Uspekhi Khimii, 50, 88 (1981).

16. Yu.S.Lipatov, Colloid Chemistry of Polymers, Kiev, Naukova Dumka (1984) [in Russian].

17. A.P.Safronov, Yu.M.Gabdrafikova, O.L.Ukhalina, Polymer Sci.Ser. A., 46, 541 (2004).

18. K.Manzoor, S.R.Vadera, N.Kumar et al., Solid State Commun., 129, 469 (2004).

19. Yu.S.Lipatov, M.N.Soltis, Z.N.Yaremko, Doklady AN SSSR, 258, 668 (1981).

20. A.S.Fewcett, G.D.Parfitt, A.L.Smith, Nature, 204, 775 (1964).

21. G.A.Johnson, S.M.Leccini, E.G.Smith et al., Disc. Faraday Soc., 42, 120 (1969).

22. A.A.Baran, Polymers in Dispersed Systems, Kiev, Naukova Dumka (1986) [in Russian].

23. J.Embden, J.E.Sader, M.Davidson, J.Phys. Chem. C, 113, 16342 (2009).

24. F.Csempesz, S.Rohrsetzer, P.Kovacs, Colloids Surf., 24, 101 (1987).

25. R.J.Sengwa, S.Sankhla, S.Sharma, Indian J. Chem., 46A, 1419 (2007).

26. S.Akbar, G.Sarvar, J.Chem.Soc.Pak., 32, 270 (2010).

27. V.C.Grigoras, V.Barboiu, Rev. Roumaine de Chim., 53, 127 (2008).

28. Blood Substitutes, Present and Future Perspectives, ed. by E.Tsuchida, Elsevier, Switzerland (1998). 